\title{
Essential Trace Elements and Antioxidant Status in Relation to Severity of HIV in Nigerian Patients
}

\author{
J.A. Olaniyia ${ }^{a}$ O.G. Arinolab \\ Departments of a Haematology and ${ }^{b}$ Chemical Pathology, College of Medicine, University of Ibadan, Ibadan, \\ Nigeria
}

\section{Key Words}

HIV • Oxidative stress $\cdot$ Micronutrient deficiency

\begin{abstract}
Objectives: This study was designed to determine the plasma levels of some antioxidants and trace elements in three severity groups of HIV patients compared with non-HIV-infected controls. Methods: The plasma levels of antioxidants (total antioxidant, albumin, bilirubin and uric acid) and trace elements ( $\mathrm{Mg}, \mathrm{Fe}, \mathrm{Zn}, \mathrm{Mn}, \mathrm{Cu}, \mathrm{Cr}, \mathrm{Cd}$ and $\mathrm{Se}$ ) were estimated spectrophotometrically in controls and patients with CD4 counts of $<200 ; 200-499$ and $\geq 500$ cells/ $\mu$ l. Results: Uric acid and $Z n$ were significantly higher, while vitamin $E$ and all the trace elements (except $Z n$ ) were significantly lower in HIV-infected patients compared to healthy controls. The highest level of uric acid was observed in those with CD4 counts of $<200$ cells $/ \mu l$. All the trace elements (except Zn) were higher in HIV subjects with a CD4 count of 200-499 cells $/ \mu$ l compared to $>500$ cells $/ \mu$ l. Only uric acid and $Z n$ showed significant correlation with CD4 count. Conclusion: Based on the results of this study, we recommend routine assessment and appropriate supplementation of antioxidants/trace elements in HIV subjects. This supplementation is hoped to strengthen the immune system and reduce the adverse consequences of HIV- related oxidative stress.
\end{abstract}

Copyright $\odot 2007$ S. Karger AG, Basel

\section{Introduction}

Oxidative stress is central to the pathogenesis of HIV, while excessive chronic immune activation from the viral infection has a pro-oxidant effect leading to consumption of antioxidants [1]. In the face of this pathogenesis, reduced dietary intake resulting from appetite loss, depression, oral sores, loss of livelihood, nutrient malabsorption, and impaired nutrient utilization further compounds the oxidative stress which aggravates the existing immune damage [2].

Extensive research work has shown that micronutrient supplementation in HIV-positive subjects resulted in wide range of benefits including reduced hospitalization [3], increased survival [4], increased weight gain [5], reduced morbidity/mortality [6], improved birth outcomes and infant immune status [7] and reduced mother-tochild-transmission [8]. Information on micronutrient status in Nigerians with HIV is scarce. A previous study [9] on micronutrient status of Nigerian HIV subjects did not relate micronutrient levels to the severity of HIV infection.

This study was carried out to find out whether or not differences exist in the levels of micronutrients/trace elements in Nigerian HIV patients compared with healthy controls. Another objective was to find out which of these antioxidant micronutrients and trace elements are relat-

\section{KARGER \\ Fax +41613061234 E-Mail karger@karger.ch} www.karger.com
O.G. Arinola, $\mathrm{PhD}$

Department of Chemical Pathology, College of Medicine

University of Ibadan

Ibadan (Nigeria)

Tel. +234 802345 1520, Fax +234 2241 3545, E-Mail arinolaog@doctor.com 
Table 1. Levels of antioxidants in HIV patients compared with controls

\begin{tabular}{lcccl}
\hline & HIV $(\mathrm{n}=58)$ & Controls $(\mathrm{n}=23)$ & $\mathrm{t}$ & $\mathrm{p}$ \\
\hline Albumin, g/dl & $4.98 \pm 0.96$ & $4.53 \pm 0.62$ & 0.54 & 0.59 \\
Uric acid, mg/dl & $4.61 \pm 1.57$ & $4.35 \pm 1.69$ & 2.75 & $0.01^{*}$ \\
Vitamin E, mg/l & $8.80 \pm 2.48$ & $10.33 \pm 2.27$ & 2.55 & $0.01^{*}$ \\
Total antioxidants, mM & $1.79 \pm 0.49$ & $1.63 \pm 0.61$ & 0.16 & 0.88 \\
Total bilirubin, mg/dl & $0.54 \pm 0.20$ & $0.54 \pm 0.16$ & 0.06 & 0.94 \\
Direct bilirubin, mg/dl & $0.20 \pm 0.10$ & $0.17 \pm 0.08$ & 1.18 & 0.24 \\
\hline
\end{tabular}

Statistically significant values are indicated by an asterisk. ed to the severity of HIV infection. This may allow identification of the nutritional markers that predict the progression of HIV to AIDS, thus exploring the possibility of dietary supplementation of HIV patients with antioxidant micronutrients or trace elements in the management of these patients.

\section{Materials and Methods}

Fifty-eight diagnosed asymptomatic HIV patients at the University College Hospital, Ibadan, Nigeria, and aged 18-47 years were recruited into the study. Twenty-six age-/sex-matched healthy HIV-negative health workers were recruited as controls. Informed consent was obtained from each subject before collection of blood samples, while ethical approval was obtained through University of Ibadan/University College Hospital Joint Ethics Review Committee before commencement of the study.

A sample of $5 \mathrm{ml}$ of venous blood was collected from the antecubital vein without venous stasis from each patient into an EDTA bottle. The blood samples were centrifuged in MSE centrifuge for $10 \mathrm{~min}$ at 3,500 rpm. The plasma was immediately placed in a freezer until analysis, which was done within 2 weeks of sample collection.

Total antioxidant was estimated using a standardized solution of Fe-EDTA complex that reacts with hydrogen peroxide by a Fenton type reaction, leading to the formation of hydroxyl radicals [10]. These reactive oxygen species degrade benzoate, resulting in the release of thiobarbituric acid reactive substances. The rate of inhibition of color development is proportional to the concentration of antioxidative activity. Serum total bilirubin was determined according to the method described by Doumas et al. [11]. Bilirubin reacts with diazotized sulphanilic acid (DSA) to form a red azo dye. The absorbance of this dye at $546 \mathrm{~nm}$ is directly proportional to the concentration of bilirubin in the sample. Watersoluble bilirubin glucuronides react directly with DSA, whereas the unconjugated bilirubin (indirect bilirubin) only reacts with DSA in the presence of an albumin.

Vitamin E was determined by the method of Baker and Frank [12]. Vitamin E was extracted in xylene and reacted with $\mathrm{x}$-dipyridyl in the presence of ferric chloride to induce a reddish color that is proportional to the concentration of the vitamin E present in the serum. The optical density was read at $520 \mathrm{~nm}$. Serum uric acid was determined by the uricase method described by Davies et al. [13]. Incubation of uric acid with uricase results in the production of $1 \mathrm{~mol}$ of allantoin and $1 \mathrm{~mol}$ of $\mathrm{H}_{2} \mathrm{O}_{2}$, respectively, for every mole of oxidized uric acid. The resulting $\mathrm{H}_{2} \mathrm{O}_{2}$ reacts with 3, 5-dichloro-2-hydroxybenzenesulfonic acid and 4-aminophenazone to give a red-violet quinoneimine dye as indicator. This was read at $546 \mathrm{~mm}$. Albumin was determined by brilliant cresol green method [14]. Bromocresol green at $\mathrm{pH}$ below the isoelectric point of albumin reacts with albumin to cause a change in color that is proportional to the amount of albumin present. Trace elements were determined with atomic absorption spectrophotometer using a direct method, as described by Kaneko [15]. The atoms of the elements when aspirated into the atomic absorption spectrophotometer vaporize and absorb light of the same wavelength as that emitted by the element when in the excited state. CD4 in the blood was counted using Dynabead kit based on the principle of magnetic cell sorting.

\section{Statistical Analysis}

The results were expressed as mean \pm SD. Comparisons were made using Student's t test ( $\mathrm{p}<0.05$ was regarded as significant). Pearson correlation analysis was used to establish possible correlation between antioxidants/trace elements and CD4 counts.

\section{Results}

The levels of total antioxidants, albumin, and bilirubin (total and direct) in HIV patients were not significantly different compared to controls. However, uric acid was significantly higher while the level of vitamin $\mathrm{E}$ was significantly lower in HIV patients compared with the controls (table 1). The levels of the trace elements are shown in table 2 and all except $\mathrm{Zn}$ were significantly lower in HIV patients compared to controls.

The mean values of albumin, uric acid, vitamin E, total antioxidant, total bilirubin, and direct bilirubin were not significantly different in HIV patients with a CD4 count of $<200$ cells/ $\mu$ l compared with $200-499$ cells/ $\mu l$ (table 3). The levels of albumin and total antioxidant were significantly higher, while the levels of the direct biliru$\operatorname{bin}(p=0.00)$, uric acid $(p=0.04)$ and vitamin $E(p=0.00)$ 
were significantly lower in HIV patients with 500-800 cells/ $\mu$ l compared with HIV patients having a CD 4 count of $<200$ cells/ $\mu$ l. Albumin and total antioxidant were significantly higher, while uric acid and vitamin E were significantly lower in HIV patients with $>500$ cells $/ \mu \mathrm{l} \mathrm{com-}$ pared with HIV having a CD4 count of 200-499 cells/ $\mu$ l. $\mathrm{Mg}, \mathrm{Fe}, \mathrm{Zn}, \mathrm{Mn}, \mathrm{Cu}, \mathrm{Cr}, \mathrm{Cd}$ and Se were not significantly reduced in HIV patients with $\mathrm{CD} 4<200$ cells/ $\mu \mathrm{l} \mathrm{com-}$ pared with HIV patients having CD4 200-499 cells/ $\mu$ l (table 4). A similar result was observed in HIV patients with CD4 $<200$ cells/ $\mu$ l compared with HIV patients having $>500$ cells $/ \mu$ l.

The levels of $\mathrm{Mg}, \mathrm{Mn}, \mathrm{Cu}, \mathrm{Cr}, \mathrm{Cd}$, and Se were significantly higher in HIV patients with CD4 200-499 cells/ $\mu$ l compared with HIV patients with CD4 500-800 cells/ $\mu$ l.

Table 2. Levels of trace elements in HIV patients compared with controls

\begin{tabular}{lccll}
\hline & HIV $(\mathrm{n}=58)$ & Controls $(\mathrm{n}=23)$ & $\mathrm{t}$ & $\mathrm{p}$ \\
\hline $\mathrm{Mg}, \mu \mathrm{g} / \mathrm{dl}$ & $47.05 \pm 16.80$ & $68.43 \pm 13.50$ & 5.44 & $0.00^{*}$ \\
$\mathrm{Fe}, \mu \mathrm{g} / \mathrm{dl}$ & $49.60 \pm 17.71$ & $80.83 \pm 17.25$ & 7.20 & $0.00^{*}$ \\
$\mathrm{Zn}, \mu \mathrm{g} / \mathrm{dl}$ & $293.90 \pm 23.02$ & $119.26 \pm 29.30$ & 9.64 & $0.00^{*}$ \\
$\mathrm{Mn}, \mu \mathrm{g} / \mathrm{dl}$ & $49.34 \pm 17.63$ & $70.35 \pm 10.46$ & 5.34 & $0.00^{*}$ \\
$\mathrm{Cu}, \mu \mathrm{g} / \mathrm{dl}$ & $45.87 \pm 15.91$ & $61.22 \pm 9.90$ & 4.23 & $0.00^{*}$ \\
$\mathrm{Cr}, \mu \mathrm{g} / \mathrm{dl}$ & $4.72 \pm 1.77$ & $6.20 \pm 1.42$ & 3.55 & $0.00^{*}$ \\
$\mathrm{Cd}, \mu \mathrm{g} / \mathrm{dl}$ & $4.93 \pm 1.76$ & $5.97 \pm 1.32$ & 5.7 & $0.00^{*}$ \\
$\mathrm{Se}, \mu \mathrm{g} / \mathrm{dl}$ & $4.54 \pm 1.78$ & $5.91 \pm 1.06$ & 3.66 & $0.00^{*}$ \\
\hline
\end{tabular}

Statistically significant values are indicated by an asterisk.
In these two groups of HIV patients, the level of $\mathrm{Zn}$ was significantly lower while Fe did not show any statistically significant difference.

Uric acid was negatively correlated with CD4 counts $(\mathrm{r}=-0.29, \mathrm{p}=0.03)$, while albumin, vitamin $\mathrm{E}$, total antioxidant, total bilirubin and direct bilirubin did not show significant correlation. Zn had a positive correlation with CD4 counts $(\mathrm{r}=+0.27, \mathrm{p}=0.04)$, while $\mathrm{Mg}, \mathrm{Fe}$, $\mathrm{Mn}, \mathrm{Cu}, \mathrm{Cr}, \mathrm{Cd}$ and Se did not show significant correlation.

\section{Discussion}

Although serum and plasma levels of micronutrients are assumed to be imperfect indicator of body stores, it has been shown that their deficiencies are common among HIV-infected persons, especially in those who are underprivileged and undernourished [16]. Micronutrients play important roles in maintaining immune function and neutralizing the reactive oxygen intermediates produced by activated macrophages and neutrophils. Undernourishment and micronutrient deficiencies in HIVinfected individuals exacerbate immunosuppression, oxidative stress, acceleration of HIV replication and CD4+ $\mathrm{T}$ cell depletion [1]. CD4+ T cells are helper T lymphocytes which are preferentially destroyed by HIV, thus the level of CD4+ T cells is reduced with the severity of HIV infection.

This study demonstrated lower levels of trace elements $(\mathrm{Mg}, \mathrm{Fe}, \mathrm{Mn}, \mathrm{Cu}, \mathrm{Cr}, \mathrm{Cd}$, and $\mathrm{Se}$ ) and vitamin $\mathrm{E}$, higher levels of uric acid and zinc, and no significant difference

Table 3. Comparison of levels of antioxidants between different severity groups of HIV patients

\begin{tabular}{|c|c|c|c|c|c|c|}
\hline & \multicolumn{3}{|l|}{ CD 4 counts } & \multirow[t]{2}{*}{$\mathrm{t} ; \mathrm{p}$ values ${ }^{\mathrm{a}}$} & \multirow[t]{2}{*}{$\mathrm{t} ; \mathrm{p}$ values ${ }^{\mathrm{b}}$} & \multirow[t]{2}{*}{$\mathrm{t} ; \mathrm{p}$ values ${ }^{\mathrm{c}}$} \\
\hline & $\begin{array}{l}<200 \text { cells } / \mu \mathrm{l} \\
(\mathrm{n}=10)\end{array}$ & $\begin{array}{l}200-499 \text { cells } / \mu \mathrm{l} \\
(\mathrm{n}=26)\end{array}$ & $\begin{array}{l}500-800 \text { cells } / \mu \mathrm{l} \\
(\mathrm{n}=20)\end{array}$ & & & \\
\hline Albumin, g/dl & $4.30 \pm 0.75$ & $4.63 \pm 1.08$ & $6.16 \pm 1.55$ & $0.46 ; 0.65$ & $7.89 ; 0.00^{*}$ & $7.30 ; 0.00^{*}$ \\
\hline Uric acid, mg/dl & $4.96 \pm 1.19$ & $4.85 \pm 1.71$ & $3.91 \pm 1.25$ & $0.18 ; 0.86$ & $2.21 ; 0.04^{*}$ & $2.08 ; 0.04^{*}$ \\
\hline Vitamin E, mg/l & $9.25 \pm 2.28$ & $9.23 \pm 2.33$ & $8.03 \pm 2.67$ & $0.03 ; 0.98$ & $2.22 ; 0.04^{*}$ & $2.62 ; 0.04^{*}$ \\
\hline Total antioxidant, $\mathrm{mM}$ & $0.91 \pm 0.35$ & $1.25 \pm 0.81$ & $3.03 \pm 0.28$ & $1.27 ; 0.21$ & $8.80 ; 0.00^{*}$ & $4.11 ; 0.00^{*}$ \\
\hline Total bilirubin, mg/dl & $0.59 \pm 0.20$ & $0.56 \pm 0.21$ & $0.51 \pm 0.18$ & $0.36 ; 0.72$ & $1.18 ; 0.25$ & $0.99 ; 0.33$ \\
\hline Direct bilirubin, mg/dl & $0.23 \pm 0.13$ & $0.21 \pm 0.10$ & $0.18 \pm 0.08$ & $0.45 ; 0.65$ & $2.23 ; 0.04^{*}$ & $0.99 ; 0.33$ \\
\hline
\end{tabular}

Statistically significant values are indicated by an asterisk.

a $<200$ CD 4 cells/ $\mu$ l compared with 200-499 CD4 cells/ $\mu l$.

b 200 CD 4 cells/ $\mu$ l compared with $\geq 500$ CD 4 cells/ $\mu l$.

c 200-499 CD4 cells/ $\mu$ l compared with $\geq 500$ CD4 cells/ $\mu$ l. 
Table 4. Comparison of levels of trace elements in different severity groups of HIV patients

\begin{tabular}{|c|c|c|c|c|c|c|}
\hline & \multicolumn{3}{|l|}{ CD4 count } & \multirow[t]{2}{*}{$\mathrm{t} ; \mathrm{p}$ values ${ }^{\mathrm{a}}$} & \multirow[t]{2}{*}{$\mathrm{t} ; \mathrm{p}$ values ${ }^{\mathrm{b}}$} & \multirow[t]{2}{*}{$\mathrm{t} ; \mathrm{p}$ values ${ }^{\mathrm{c}}$} \\
\hline & $\begin{array}{l}<200 \text { cells } / \mu \mathrm{l} \\
(\mathrm{n}=10)\end{array}$ & $\begin{array}{l}200-499 \text { cells } / \mu \mathrm{l} \\
(\mathrm{n}=24)\end{array}$ & $\begin{array}{l}500-800 \text { cells } / \mu l \\
(\mathrm{n}=20)\end{array}$ & & & \\
\hline $\mathrm{Mg}, \mu \mathrm{g} / \mathrm{dl}$ & $47.80 \pm 28.12$ & $52.48 \pm 15.64$ & $40.20 \pm 13.15$ & $0.72 ; 0.48$ & $1.88 ; 0.25$ & $2.84 ; 0.01^{*}$ \\
\hline $\mathrm{Fe}, \mu \mathrm{g} / \mathrm{l}$ & $48.80 \pm 22.18$ & $53.26 \pm 14.38$ & $46.00 \pm 19.34$ & $0.72 ; 0.48$ & $0.36 ; 0.72$ & $1.48 ; 0.15$ \\
\hline $\mathrm{Zn}, \mu \mathrm{g} / \mathrm{dl}$ & $126.10 \pm 55.68$ & $53.26 \pm 14.38$ & $600.10 \pm 22.52$ & $0.70 ; 0.49$ & $0.67 ; 0.5$ & $10.67 ; 0.00^{*}$ \\
\hline $\mathrm{Mn}, \mu \mathrm{g} / \mathrm{dl}$ & $49.70 \pm 22.59$ & $55.37 \pm 15.48$ & $41.89 \pm 15.38$ & $0.87 ; 0.39$ & $1.12 ; 0.27$ & $2.96 ; 0.01^{*}$ \\
\hline $\mathrm{Cu}, \mu \mathrm{g} / \mathrm{dl}$ & $47.90 \pm 20.59$ & $51.07 \pm 12.45$ & $38.43 \pm 15.48$ & $0.57 ; 0.57$ & $1.42 ; 0.17$ & $3.10 ; 0.00^{*}$ \\
\hline $\mathrm{Cr}, \mu \mathrm{g} / \mathrm{l}$ & $4.71 \pm 2.23$ & $5.32 \pm 1.77$ & $4.05 \pm 1.28$ & $0.86 ; 0.40$ & $1.04 ; 0.31$ & $2.71 ; 0.01^{*}$ \\
\hline $\mathrm{Cd}, \mu \mathrm{g} / \mathrm{l}$ & $4.93 \pm 2.23$ & $5.50 \pm 1.73$ & $4.25 \pm 1.30$ & $0.82 ; 0.42$ & $1.06 ; 0.30$ & $2.71 ; 0.1^{*}$ \\
\hline Se, $\mu \mathrm{g} / \mathrm{dl}$ & $4.68 \pm 2.19$ & $4.97 \pm 1.73$ & $3.72 \pm 1.44$ & $0.42 ; 0.68$ & $1.45 ; 0.16$ & $2.64 ; 0.01^{*}$ \\
\hline
\end{tabular}

Statistically significant values are indicated by an asterisk.

${ }^{a}<200$ CD 4 cells/ $\mu$ l compared with 200-499 CD4 cells/ $\mu 1$.

b 200 CD 4 cells/ $\mu$ l compared with $\geq 500$ CD 4 cells/ $\mu l$.

c 200-499 CD4 cells/ $\mu$ l compared with $\geq 500$ CD 4 cells $/ \mu l$.

in the levels of total antioxidant, albumin and bilirubin in HIV patients when compared with controls; their levels in intra-CD4-group comparison showed consistently lower levels in HIV patients with lower CD4 counts, thereby correlating with severity.

Ames et al. [17] described uric acid as a powerful scavenging antioxidant. Manfredi et al. [18] reported a correlation between hyperuricemia and progression of HIV disease as observed in this study. This high uric acid level might be due to rapid cell turnover and muscle wasting as a consequence of oxidative damage to polyunsaturated fatty acid. Uric acid binds ions of copper and iron. Therefore, increased concentration of uric acid gives a falsely elevated concentration of copper and iron, and thus may prevent availability/utilization by tissues.

Vitamin E, which was found to be lower in HIV patients compared with controls, is a result of its increased utilization in quenching free radicals and thereby prevents peroxidation of polyunsaturated fatty acids. Poor dietary intake, poor absorption and diarrhea in HIV subjects contribute to the reduced level of vitamin $\mathrm{E}$ in HIV subjects. It is also possible that the recycling mechanism of biologically active vitamin E through ascorbate is impaired in HIV patients. Coutsoudis et al. [19] reported low vitamin $\mathrm{E}$, along with vitamin $\mathrm{A}$ and $\beta$-carotene as part of biochemical manifestations in HIV/AIDS patients. In this study, progressive reduction in vitamin $\mathrm{E}$ level in HIV patients was observed when the three severity groups were compared. Studies had shown that double intake of vitamin $\mathrm{E}$ decreased the risk of progression to
AIDS [20]. However, there was no correlation between vitamin $\mathrm{E}$ and CD4 count in our study. Therefore, vitamin E level may be used as a marker of severity in HIV infection.

When HIV patients and controls were compared, albumin, total antioxidant, and bilirubin levels did not show any statistically significant difference. This may suggest minimal oxidative injury from oxidative stress, fairly good nutritional status, and healthy hepatic status. According to Lichterfeld et al. [21], liver function tests become abnormal in $60-70 \%$ of AIDS patients and bilirubin usually remains normal. However, a high bilirubin commonly arises from bacteria sepsis, chronic active hepatitis and micronodular cirrhosis. Therefore, it is not surprising that HIV patients with CD $4<200$ cells/ $\mu$ l is the only group whose bilirubin was significantly raised when compared with those with $>500$ cells $/ \mu$ l.

A low albumin level carries a poor prognosis but is a strong independent predictor of mortality [9]. Albumin is equally a determinant of nutritional status, hepatic function and renal protein wasting [22]. Comparison of the three severity groups showed consistently decreasing levels of albumin and total antioxidant and consistently increasing levels of uric acid and vitamin $\mathrm{E}$ in those with low CD4 counts. The reason for the higher level of vitamin $\mathrm{E}$ in HIV individuals with lower CD4 count among the severity groups remains elusive. However, unregulated vitamin supplementations may be responsible.

Lower levels of trace elements were observed in HIV patients when compared with controls, but statistically 
significant higher levels of trace elements were obtained in patients with a CD4 count of 200-499 cells/ $\mu$ l compared with those with $>500$ cells/ $\mu$ l. Other severity groups did not show any statistically significant differences. This is again difficult to explain but overzealous supplementation may also be accountable.

In this study, the level of zinc was statistically significantly higher in HIV-infected subjects compared with the controls. Arinola et al. [9] found lower levels of some trace elements (such as $\mathrm{Cu}, \mathrm{Mg}, \mathrm{Fe}, \mathrm{Zn}, \mathrm{Cd}$, Se and $\mathrm{Cr}$ ) compared to controls, and also observed similar levels of zinc in asymptomatic HIV-infected patients compared with controls. The contrast between their result and the result of the present study may be due to subject selection. Arinola et al. [9] recruited asymptomatic HIV subjects whose CD4 count or immune status may still be close to normal. It is therefore possible that changes in zinc level occur when the immune system or CD4 count is falling, and thus may be a useful indicator of advanced HIV infection.

Zinc level may be normal or high in asymptomatic HIV-infected patients, and a steady decline is expected as immunodeficiency sets in. The raised level of zinc in HIV-infected subjects compared with controls may also be part of an unregimented measure to manage this disease in this environment. Most infected individuals accept all forms of unorthodox treatment, part of which usually includes the use of herbs and dietary advice. Some of these may be a source of zinc to these patients. High level of zinc in these patients could be beneficial since zinc could be both an inhibitor of reverse transcriptase and an activator of the 'tat' protein. Caselli and Biochi [23] demonstrated an increase in CD4 cells and reduced progression of disease when zinc sulphate supplementation was given to AIDS patients with low zinc level. As documented earlier, most trace elements studied are usually linked directly or indirectly with several metalloenzymes having antioxidant activities. Therefore, their de- ficiencies in HIV-infected subjects may be due to consumption as a result of oxidative stress.

Apart from dietary supplementation, the involvement of cytokines in regulating the levels of certain trace elements should be considered. Cytokines play an important role in controlling the homeostasis of the immune system, and HIV infection results in deregulation of the cytokine profile. During the course of HIV infection, secretion of proinflammatory cytokines (IL-1, IL-6 and IL-8) is increased [24]. Production of proinflammatory cytokine is known to lower the plasma levels of $\mathrm{Fe}$ and $\mathrm{Zn}$ but raises that of $\mathrm{Cu}$ [25]. This study showed a reduced level of $\mathrm{Cu}$, which could be due to reduction in the synthesis of ceruloplasmin by liver. Reduced synthetic function of the liver and negative influence of proinflammatory cytokines on albumin synthesis could also explain the low level of albumin in HIV patients. Albumin is a negative acute-phase reactant that is reduced during infection and inflammation, thus its importance in being a predictor of mortality. This explains why a lower CD4 count is associated with reduced albumin concentration.

It is plausible that the results obtained in this study could be due to dietary deficiency of trace elements or cytokine-driven inflammatory responses.

\section{Conclusion}

This study supports the fact that oxidative stress culminates into deficiency of antioxidants/some micronutrients in HIV-infected individuals with consequent tissue damage, and demonstrates that uric acid and zinc show a clear correlation with the severity of HIV. Routine assessment of antioxidant/trace element levels in HIV subjects is recommended so that appropriate supplementation with antioxidants/trace elements is advised for HIV patients with demonstrably low levels in order to limit oxidative stress.

\section{References}

1 Fuchs J, Ochsendorf F, Schofer H: Oxidative imbalance in HIV infected patients. Med Hypotheses 1991;36:60-64.

2 Bruce A Feeman, M James D, Crapo MD: Free radials and tissue injury. Lab Invest 1962;49:412-425

- 3 Semba RD, Tang AM: Micronutrients and pathogenesis of human immunodeficiency virus infection. Br J Nutr 1999;81:181-189.

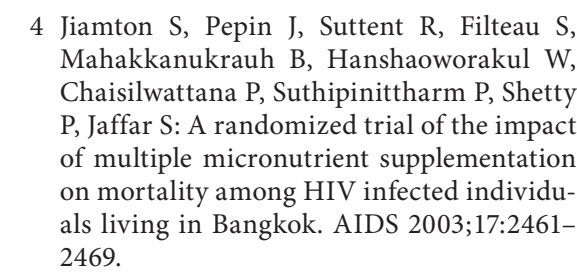

Jiamton S, Pepin J, Suttent R, Filteau S Mahakkanukrauh B, Hanshaoworakul W, f multiple randon on mortality among HIV infected individu2469.

\footnotetext{
5 Villamor G, Mzanga G, Spiegelman D, Antelman G, Hunter DJ, Fawzi WW: Effect of multivitamin and vitamin A supplements on weight gain during pregnancy among HIV-1 infected women. Am J Clin Nutr 2002;76: 1082-1090.

6 World Health Organization: Global situation of the HIV/AIDS pandemic. Bull World Health Organ 2003;78:417-474.
} 
7 Fawzi W, Msamanga G, Hunter D: Randomized trial of vitamin supplements in relation to transmission of HIV-1 through breastfeeding and early child mortality. AIDS 2002;16:1935-1944.

-8 Fawzi W: Micronutrients and human immunodeficiency virus type 1 disease progression among adults and children. Clin Infect Dis 2003;37(suppl 2):S112-S116

$\checkmark 9$ Arinola OG, Adedapo KS, Kehinde AO, Olaniyi JA, Akiibinu MO: Acute phase proteins and trace elements in asymptomatic human immunodeficiency virus infection in Nigerians. Afr J Med Sci 2004;33:317-322.

10 Grey CE, Adlercreutz P: Evaluation of multiple oxidation products for monitoring effects of antioxidants in Fenton oxidation of 2 '-deoxyguanosine. J Agric Food Chem 2006;54:2350-2358.

11 Doumas BT, Kwok-Cheung P, Perry BW, Jendrzejczak B, McComb RB, Schffer R, Hause LL: Candidate reference method for determination of total bilirubin in serum: development and evaluation. Clin Chem 198;31: 1677-1682.
12 Baker H, Frank O: Determination of vitamin E; in Baker H, Frank O (eds): Clinical Vitaminology: Methods and Interpretation. New York, Wiley, 1968, pp 172-176.

13 Davies KJ, Sevanian A, Mkuakkassah-Kelly SF, Hochstein P: Uric-acid-iron complex: new aspect of anti-oxidant functions of uric acid. Biochem J 1986;235:747-754.

14 Spencer K, Price CR: The determination of serum albumin using bromocresol green. Ann Clin Biochem 1977;14:105.

15 Kaneko JJ (ed): Clinical Biochemistry of Animals, ed 4. New York, Academic Press, 1999, p 932.

16 Barbara M, Kevin M: Multivitamins, nutrition and antiretroviral therapy for HIV disease in Africa. New Engl J Med 2004;351: 78-80.

17 Ames BN, Shigenaga MK, Hagen TM: Oxidants, antioxidants and the degenerative diseases of ageing. Proc Natl Acad Sci USA 1993;90:7915-7922.

18 Manfredi R, Mashoianni A, Olgia V, Chiodo F: Hyperuricaemia and progression of HIV disease. J Acquir Immune Defic Syndr Hum Retrovirol 1996;12:318-319.

19 Coutsoudis A, Bobat R, Coovadia HM: The effect of vitamin A supplementation on the morbidity of children born to HIV infected women. Am J Public Health 1995;85:76-80.
20 Tang MA, Graham NH, Semba R, Saah AJ: Association between serum vitamin $\mathrm{A}$ and $\mathrm{E}$ levels and HIV-1 disease progression. AIDS 1997;11:613-620.

21 Lichterfeld M, Haas S, Fischer HP, Voigt E, Rockstroh JK, Spengler U: Liver histopathology in human immunodeficiency virus-hepatitis $\mathrm{C}$ virus co-infected patients with fatal liver disease. J Gastroenterol Hepatol 2005; 20:739-745.

$>22$ Feldman JG, Gange ST, Bacchet P, Chen M, Young M, Squires K, Williams C, Goldwassex $\mathrm{P}$, Anastos K: Serum albumin is a powerful predictor of survival among HIV-1 infected women. J AIDS 2003;33:66-73.

23 Caselli M, Biochi R: Serum zinc levels in patient with acquired immunodeficiency syndrome. Press Med 1996;15:1877-1886.

24 Kedzierska K, Crowe SM: Cytokines and HIV: Interactions and clinical implications. Antivir Chem Chemother 2001;12:133-150.

25 Klaus-Helge I, Lothar R: Zinc - altered immune function. J Nutr 2003;133:1452514565. 